\title{
A Reassessment of The "Excess Return Phenomenon" For Initial Public Offerings of Common Stock
}

\author{
Dr. Glenn A. Wolfe, Finance, University of Toledo \\ Dr. Elizabeth S. Cooperman, Finance, University of Baltimore
}

\begin{abstract}
This study examines the relationship between underpricing for new issues of common stock and issue size (offer price and number of shares) after controlling for an issue's risk. Both risk and offer price are found to be significant factors in explaining underpricing. Offer price dominates as an explanatory variable in cold issue markets, while risk dominates in hot issue markets.
\end{abstract}

\section{Introduction}

The "excess return phenomenon" for new stocks remains largely a mystery. This phenomenon has been particularly an enigma with respect to hot issue markets, markets where excess returns on new issues have been found to be abnormally high relative to previous periods (Ibbotson and Jaffe, 1975; Ritter 1984). Although a number of researchers have examined this phenomenon, the reason for observed abnormal returns is still unclear. Academicians have proposed that excess returns are the result of information asymmetries (Beatty and Ritter 1986; Ritter 1984; Rock 1986; 1982) or the institutional structure of the initial public offering (IPO) issuing process (Chalk and Peavy 1985, 1986, 1987). Recently, the possibility of a small firm effect (Banz 1981; Reinganum 1981) to explain after-market excess returns for smaller issues has been proposed (Chalk and Peavy 1985).

An understanding of the new stock pricing anomaly is important for all participants in the new issues market. The objective of this study is to more thoroughly examine possible rationales for abnormal returns on new issues, particularly in terms of a small-firm versus an information asymmetry explanation. The following section presents recent theories for new issue underpricing and previous empirical tests of the theories. Section III explains the data and test design followed by an analysis of the empirical results and a final summary.

\section{Theoretical Models of Underpricing}

\section{A. Theoretical Explanations}

Recent explanations for the underpricing phenomenon focus on either asymmetries in information or on institutional factors (Smith 1986). The asymmetry models center on two types of informational disparities. In the first type of asymmetry, there is a disparity in the information available to the issuer versus the underwriter (Baron 1982). The issuer is at risk, since the investment banker has better information regarding capital market conditions than the issuer, and the distribution effort of the investment banker cannot be observed. The issuer must compensate the banker for his superior information, and new issues will be more underpriced the less informed the issuer is concerning the demand for the issue in the capital markets.

A variation of this type of asymmetric information argument is based on Klein and Leffler's (1981) certification hypothesis. Under this argument, issuers have greater inside information than underwriters. Because of information asymmetries, underwriters are employed to certify that the offer price is consistent with both publicly available information and inside information 
concerning the firm in question. Underwriting costs include costs by the investment banker to certify an issue's value. The greater the firmspecific risk and the smaller the firm, the higher will be the underwriter's certification cost. Booth and Smith (1986) suggest that less prestigious, less-established underwriters may underprice issues and absorb a loss to build their reputation capital in terms of certification.

The second type of asymmetry explanation focuses on asymmetries between informed and uninformed investors rather than between underwriters and the issuing firm (Beatty and Ritter 1986; Ritter 1984; Rock 1986, 1982). Informed investors have incurred costs to know the value of new issues, while uninformed investors have not. Because informed investors are bidding for highly valued issues, these issues will be rationed and uninformed investors will be able to acquire only non-rationed, less valuable issues (i.e., the "winner's curse"). Investment bankers desiring to attract marginal investors must underprice on average before uninformed investors will be willing to come into the market. The more uncertain the demand for an issue, the greater must be the underpricing, so that uninformed investors can obtain sufficient compensation for expected losses on overpriced issues. If underpricing is not based on ex-ante uncertainty, underwriters will be penalized by the marketplace.

Carter and Manaster (1987) expanded on Rock's $(1982,1986)$ model by proposing that the level of investment banker prestige is negatively related to the risk of IPOs and the number of informed investors accessing information on IPOs. Since prestigious investment bankers underwrite less risky issues, there would be less incentive for investors to acquire additional information and thus fewer informed investors. Consequently, an inverse relationship between the level of investment banker prestige and the degree of underpricing would be expected.

Chalk and Peavy $(1985,1987)$ focus instead on the institutional nature of the IPO bidding process. Given pricing rules for new issues, underwriters must offer one price to all investors for any offering. They can, however, preferentially ration oversubscribed issues to their best customers, a type of discriminatory auction. Customers, in turn, pay for this privilege by buying tied-in services, which allows underwriters to cover their fixed costs and obtain a commensurate return. Since in a discriminatory auction bidders adjust their bids downwards relative to optimal competitive bids, the minimum accepted bid will be lower than the aftermarket price. The apparent underpricing in the immediate aftermarket on the initial day of trading is not underpricing per se, but the result of a price adjustment process of IPOs offered under such an auction. Implications of the model are: (1) there should be no abnormal price performance on average after the first day of trading; and (2) there should not be a monotonic relationship between excess returns and aftermarket price uncertainty. Since only preferential customers are entitled to initial day price appreciation, small investors are not able to earn excess returns on new issues.

Tinic (1988) recently developed a theory of underpricing based on the risk of legal liabilities and potential damages to the reputations of investment bankers that are associated with the performance of due diligence examinations of new issues. Underpricing is hypothesized to serve as a form of insurance against such damages. With greater potential liabilities and criminal penalties for failing to follow due diligence and disclosure requirements, greater underpricing would be expected to occur in the post Security Exchange Act of 1933 period. Underpricing would also be expected to be a function of the difficulty in evaluating a new issue. New issues of smaller, less well-known companies would be expected to be more underpriced. Unlike the previously discussed theories, rationing in the new issues market is not assumed to be an important factor in underpricing.

\section{B. Empirical Studies}

Empirical tests of asymmetric models have attempted to determine whether a monotonic relationship exists between abnormal returns and the expected aftermarket price uncertainty of new issues. Using returns based on the first available stock price in aftermarket trading for 1,028 new issues during the period 1977-1982, Ritter (1984) observed a monotonoic relationship between excess returns and respective ex-ante and ex-post risk proxies - sales level and the standard deviation of returns. The largest excess returns, however, occurred for natural resource 
The Journal of Applied Business Research - Vol. 6, No. 1

issues during the January 1980-March 1981 hot issue market, including a concentration of lowpriced (penny) stocks issued in a regional (Denver) market.

Beatty and Ritter (1986) subdivided Ritter's sample into 438 firms going public between 1977 and the first quarter of 1981 and 545 firms, between the second quarter of 1981 and 1982 . In addition to finding a monotonic relationship between abnormal returns and ex-post risk proxies (the reciprocal of gross proceeds and the number of uses listed for gross proceeds), they discovered that underwriters with a large degree of underpricing in the first sub-period that was not based on aftermarket price risk lost market share in the latter subperiod.

Miller and Reilly (1987), using daily data for 510 new issues during 1982-1983, found excess returns to disappear after the initial trading day. They also found, however, a positive correlation between underpriced issues and risk proxies including an ex-post proxy - the standard deviation of returns for the first five trading days and an ex-ante proxy - the inverse of an issues's gross proceeds. For overpriced issues the correlation with the risk proxies was negative.

In another study using daily data, Chalk and Peavy $(1985,1986,1987)$ examined a sample of 659 IPOs issued between 1975 and 1982. They observed the disappearance of mean excess returns after the initial day of trading except for very low-priced issues. On the initial day of trading, offerings of $\$ 1$ or less also had much higher average returns $(56.43 \%$ vs. $21.65 \%)$ than the entire sample. Since a large number of issues in their sample were low-priced issues (33\% with share prices less than \$2), Chalk and Peavy concluded there might be a sampling bias. They observed a decline in market-adjusted excess returns in the aftermarket as the average price of an IPO increased and suggested that a small firm effect might be operating similar to that found by Banz (1981) and Reinganum (1981).

In a recent study examining initial returns for 962 new issues during 1981-1983 Johnson and Miller (1988) found that once risk is held constant, investment banker prestige is not a significant factor in explaining initial returns. However, risk (measured by the standard deviation of aftermarket returns for the first 15 trading days) was found to be negatively related to underwriter prestige. In addition, a positive relationship between offer size and underwriter prestige was discovered.

Tinic (1988) examined the excess returns for the first week after the offering date for 70 new issues during the pre-SEC period 1923-1930 and 134 in the post-SEC period 1966-1971. Tinic found underpricing to be significantly larger in the latter period, supporting an implicit insurance hypothesis. However, Tinic did not find excess returns to be significantly related to small issues (proxied by offering size and offering price) in the post-SEC period, as expected under his hypothesis.

\section{Size as a Proxy for Estimation and/or Li- quidity Risk}

Size and the standard deviation of aftermarket returns have been used interchangeably in previous studies as proxies for risk in terms of the ex-ante uncertainty of the demand for a new issue. Size, however, may represent a distinct type of security estimation risk similar to that previously observed in studies examining the performance of stocks in the secondary market. Banz (1981), Klein and Bawa (1977), and Barry and Brown (1984) have argued that the small firm anomaly observed in secondary markets (whereby smaller securities have risk-adjusted excess returns) might be due to a greater estimation-risk premium required for small firms. Small firms generally have shorter operating histories than large firms, and thus have relatively limited information available. Limited information in turn can have an effect on the estimation risk of an issue, and thus on the required rate of return. Barry and Brown 1984 found some empirical support for this theory by finding that period of listing, as a "crude" measure of differential information was associated with the firm-size anomaly. Smaller firms going public may also require such a premium.

This estimation risk premium, based on a model of differential information across securities, is distinct from the premium specified by Rock's (1982-1986) model based on information asymmetry between informed and uninformed investors. A small firm or estimation risk premium would be demanded by all investors, since informed investors would also be subject to the 
limited, historical information available for smaller firms. As pointed out by Barry and Brown (1984), a size-related premium would be consistent with a two-parameter risk/return model reflecting investor perceptions of differential information across securities.

Alternative types of premiums for small firms have been suggested. Chalk and Peavy (1985) suggest that a liquidity premium may be demanded for smaller issues, because they have higher transaction costs and are more thinly traded, making them harder to sell. Amihud and Mendelson (1986) observed such a liquidity premium for smaller issues in the secondary market.

In this study, the hypothesis of a size anomaly in the new issue market will be tested by examining the relationship between excess returns and size, after adjusting for risk. Previous studies, including Ibbotson's (1975) have shown that investors expect to be compensated for more than systematic risk in the new issues market. Rock states that investors must be compensated for the ex-ante uncertainty of an issue. This uncertainty is noted by Ritter to be highly correlated with an issue's aftermarket price variance. Therefore, the measure that will be used to adjust for the risk of an issue is the standard deviation of aftermarket returns, as utilized in previous studies by Johnson and Miller (1988) and Ritter (1987).

\section{Methodology}

\section{A. Data and Sample Selection}

The sample consists of all initial public offerings of common stock underwritten on a firm commitment basis listed on the S.E.C. Registered Offering Statistics (ROS) magnetic tape (1986) for the years 1977-1985. IPOs underwritten on a best efforts basis are excluded from the sample, since recent studies by Ritter (1987) have noted peculiarities in the initial performance of best efforts versus firm commitment offerings. The sample is also limited to offerings that had daily returns for the first 100 trading days contained on the CRSP NASDAQ tape. When the sample is divided into deciles by offer price, the offer prices for the sample range from an average price of $\$ 2.11$ in the lowest decile to $\$ 21.11$ in the top decile as shown in Table 1 . The average number of shares outstanding per decile ranges from .908 to 3.182 million. All reported returns are daily market-adjusted excess returns equal to the difference between the return on an IPO for a given day and the return on the NASDAQ index for the corresponding day.(1) Initial day IPO returns are calculated using the initial offer price and the offer day average bid-ask price.

\section{B. Empirical Tests}

To test the hypothesis of a small firm effect for new issues, Kross's (1985) methodology is used which decomposes the market value of an issue into its two components: Price (PRC) and Shares Outstanding (SHS). The natural logarithm of each of these variables is employed in the model because of a predicted declining marginal effect of increases in these variables on excess returns. This decomposition was used by Kross to determine whether the small firm effect observed for secondary issues was a function of share price and/or the number of traders in a market as proxied by the number of shares out-

TABLE 1: AVERAGE PRICE BY OFFER PRICE DECILE

\begin{tabular}{lllllllllllll}
\hline Decile & 1 & 2 & 3 & 4 & 5 & 6 & 7 & 8 & 9 & 10 & \\
\hline $\begin{array}{c}\text { Avg. } \\
\text { Price }\end{array}$ & 2.11 & 4.81 & 6.09 & 7.55 & 8.96 & 10.36 & 12.07 & 13.60 & 15.85 & 21.22 \\
\hline $\begin{array}{c}\text { Avg. } \\
\text { No. Shs } \\
\text { (mil.) }\end{array}$ & 3.182 & .923 & .908 & 1.030 & .977 & 1.256 & 1.147 & 1.328 & 1.578 & 1.846 \\
\hline
\end{tabular}


The Journal of Applied Business Research - Vol. 6, No. 1

standing.(2) Kross found the small firm effect to be predominantly a price effect, which he conjectured to be due to an estimation risk premium for low-priced issues.

To adjust excess returns for risk, the standard deviation of ex-post returns for the first 100 trading days (STD) is used. The model used in the cross-sectional analysis is as follows:

$r_{i}=a_{1}+B_{1}\left[\log [P R C]+B_{2}[\log (S H S)]+B_{3}(S T D)+e i\right.$

where: $r_{i}$ is the initial day excess return on security $i$ and $B_{1}, B_{2}$, and $B_{3}$ are the parameters on the respective components, and $\mathrm{e}_{\mathrm{i}}$ is a random error term.

Kross used individual firms versus portfolios in his cross-sectional analysis to avoid any bias of portfolio formulation (see Blume and Stambaugh 1983, and Roll 1983ab). Since recent studies have shown excess returns to be primarily an initial trading day phenomenon, individual security excess returns are examined for the initial day of trading.

\section{Performance in Hot vs. Cold Markets}

To determine whether there is a different pricing mechanism operating in hot issue versus cold issue markets, the sample is also partitioned by market type. To do this a hot issue market must be defined. Previous studies have defined hot issue markets somewhat arbitrary. Ritter (1984) estimated the hot issue market in his study by a visual analysis of IPO excess returns. Ibbotson and Jaffe (1975) defined a hot issue month as a month when the residuals of new issues exceeded the median of the previous month's residuals. Close scrutiny of the data employed in this study revealed that the mean excess returns for many of the quarters were clustered within 29 percent of the mean excess return over the entire sample period. However, there were some quarters in the sample with a mean excess return substantially outside this range. Therefore, this naturally occurring break in the data was used to define hot markets. That is, a hot market is defined as a quarter with mean excess returns twenty percent or higher than the mean excess return over the sampling period. These periods included the January 1980-March 1981 hot issue market identified by Ritter.

TABLE 2: AVERAGE EXCES8 RETURNS BY TRADING DAY

\begin{tabular}{|c|c|c|c|c|c|}
\hline Day & 1 & 2 & 3 & 4 & 5 \\
\hline $\begin{array}{l}\text { All Markets } \\
(N=920)\end{array}$ & $\begin{array}{l}11.538^{\star \star \star} \\
(16.929)\end{array}$ & $\begin{array}{l}0.39 q^{* * *} \\
(2.607)\end{array}$ & $\begin{array}{l}-0.08 \% \\
(-0.609)\end{array}$ & $\begin{array}{l}-0.09 \% \\
(-0.755)\end{array}$ & $\begin{array}{l}-0.16 \% \\
(-1.401\end{array}$ \\
\hline $\begin{array}{l}\text { Hot Markets } \\
(N=329)\end{array}$ & $\begin{array}{l}21.468^{\star \star \star} \\
(14.432)\end{array}$ & $\begin{array}{l}0.828^{\star * \star} \\
(2.713)\end{array}$ & $\begin{array}{l}-0.568^{* *} \\
(-2.006)\end{array}$ & $\begin{array}{l}0.04 \% \\
(0.169)\end{array}$ & $\begin{array}{l}-0.23 \% \\
(-1.057\end{array}$ \\
\hline $\begin{array}{l}\text { Cold Markets } \\
(\mathrm{N}-591)\end{array}$ & $\begin{array}{l}6.008^{* * *} \\
(11.037)\end{array}$ & $\begin{array}{l}0.168 \\
(0.979)\end{array}$ & $\begin{array}{l}0.18 \% \\
(1.256)\end{array}$ & $\begin{array}{l}-0.16 \% \\
(-1.284)\end{array}$ & $\begin{array}{l}-0.12 \% \\
(-0.93)\end{array}$ \\
\hline
\end{tabular}

T-statistics are shown in parenthesis.

*** Significant at a .01 confidence level.

* Significant at a .05 confidence level.

* Significant at a.10 confidence level. 


\section{Empirical Results}

\section{A. Analysis of Excess Returns}

The mean excess returns for the first five trading days are reported in Table 2 . The average excess return on the initial trading day was found to be $11.53 \%$ during all markets, $21.46 \%$ during hot markets, and $6.00 \%$ during cold markets (significant at the .01 level in all cases). The large difference of $15.46 \%$ between hot and cold markets is consistent with previous studies. On day 2 , the second day of trading, average excess returns of $.39 \%$ and $.82 \%$ were found for all markets and hot markets, respectively (significant at the .01 level in both cases). However, considering transactions costs investors would not be able to earn excess profits.(3) Consistent with Miller and Reilly's 1987 study, mispricing appears to be predominantly an initial trading day phenomenon.

Table 3 presents the initial day return characteristics for the hot market and cold market sub-

TABLE 3: EXCESS RETURN STATISTICS - TRADING DAY 1

"Al1 Issues"

\begin{tabular}{|c|c|c|c|c|c|}
\hline & Mean & STD & Min. & Max. & Median \\
\hline $\begin{array}{l}\text { All Markets } \\
(N=920)\end{array}$ & $11.538^{* \star *}$ & 20.668 & -27.478 & $224.99 \%$ & $3.80 \%$ \\
\hline $\begin{array}{l}\text { Hot Markets } \\
(\mathrm{N}=329)\end{array}$ & $21.458^{\star \star \star}$ & 26.978 & $-10.27 \%$ & $224.99 \%$ & $13.76 \%$ \\
\hline \multirow{3}{*}{$\begin{array}{l}\text { Cold Markets } \\
(N=591)\end{array}$} & $6.008^{\star \star \star}$ & $13.22 \%$ & -27.478 & $112.58 \%$ & $2.01 \%$ \\
\hline & \multicolumn{3}{|c|}{ "Winners" } & & \\
\hline & Mean & $\underline{\text { STD }}$ & Min. & Max. & Median \\
\hline $\begin{array}{l}\text { All Markets } \\
(N=749)\end{array}$ & $14.96 \%$ & $21.36 \%$ & $0.01 \%$ & 224.998 & $6.42 \%$ \\
\hline $\begin{array}{l}\text { Hot Markets } \\
(N=282)\end{array}$ & $25.49 q^{* \star \star}$ & $27.08 \%$ & $0.05 \%$ & $224.99 \%$ & $18.17 \%$ \\
\hline \multirow{3}{*}{$\begin{array}{l}\text { Cold Markets } \\
(\mathrm{N}-467)\end{array}$} & $8.60 \%^{\star \star \star}$ & 13.538 & $0.01 \%$ & $112.58 \%$ & $3.50 \%$ \\
\hline & \multicolumn{3}{|c|}{ "Losers" } & & \\
\hline & Mean & $\underline{\text { STD }}$ & Min. & Max. & Median \\
\hline $\begin{array}{l}\text { Al1 Markets } \\
(N=171)\end{array}$ & $-3.49 q^{\star \star \star}$ & $4.37 \%$ & $-27.48 \%$ & $-0.01 \%$ & $-2.00 \%$ \\
\hline $\begin{array}{l}\text { Hot Markets } \\
(N=47)\end{array}$ & $-2.77 q^{\star \star \star}$ & $2.75 \%$ & $-10.27 \%$ & $-0.01 \%$ & $-2.01 \%$ \\
\hline $\begin{array}{l}\text { Cold Markets } \\
(\mathrm{N}=124)\end{array}$ & $-3.77 z^{\star \star \star \star}$ & $\begin{array}{c}4.82 \% \\
45\end{array}$ & $-27.48 \%$ & $-0.04 \%$ & $-1.99 \%$ \\
\hline
\end{tabular}


The Journal of Applied Business Research - Vol. 6, No. 1

samples and for underpriced ("winners") and overpriced ("losers") issue subsamples for each respective market. The hot markets are shown to be more volatile than the cold markets. The data in the first panel of Table 3 reveals a larger standard deviation (26.97\% versus $13.22 \%$ ) and range $235.25 \%$ vs. $140.05 \%$ ) for initial day returns across all issues in hot markets. This is also true across all winners as shown in the second panel. The average excess return on winners was $196 \%$ higher in hot markets. For losers, as shown in the third panel, the means, range, and standard deviation were slightly higher in cold markets. Over $81 \%$ of the issues in the sample were winners (79\% of the issues in cold markets and $85.7 \%$ of the issues in hot markets).

TABLE 4: CROSS-SECTIONAL REGRESSION RESULTS

All Issues

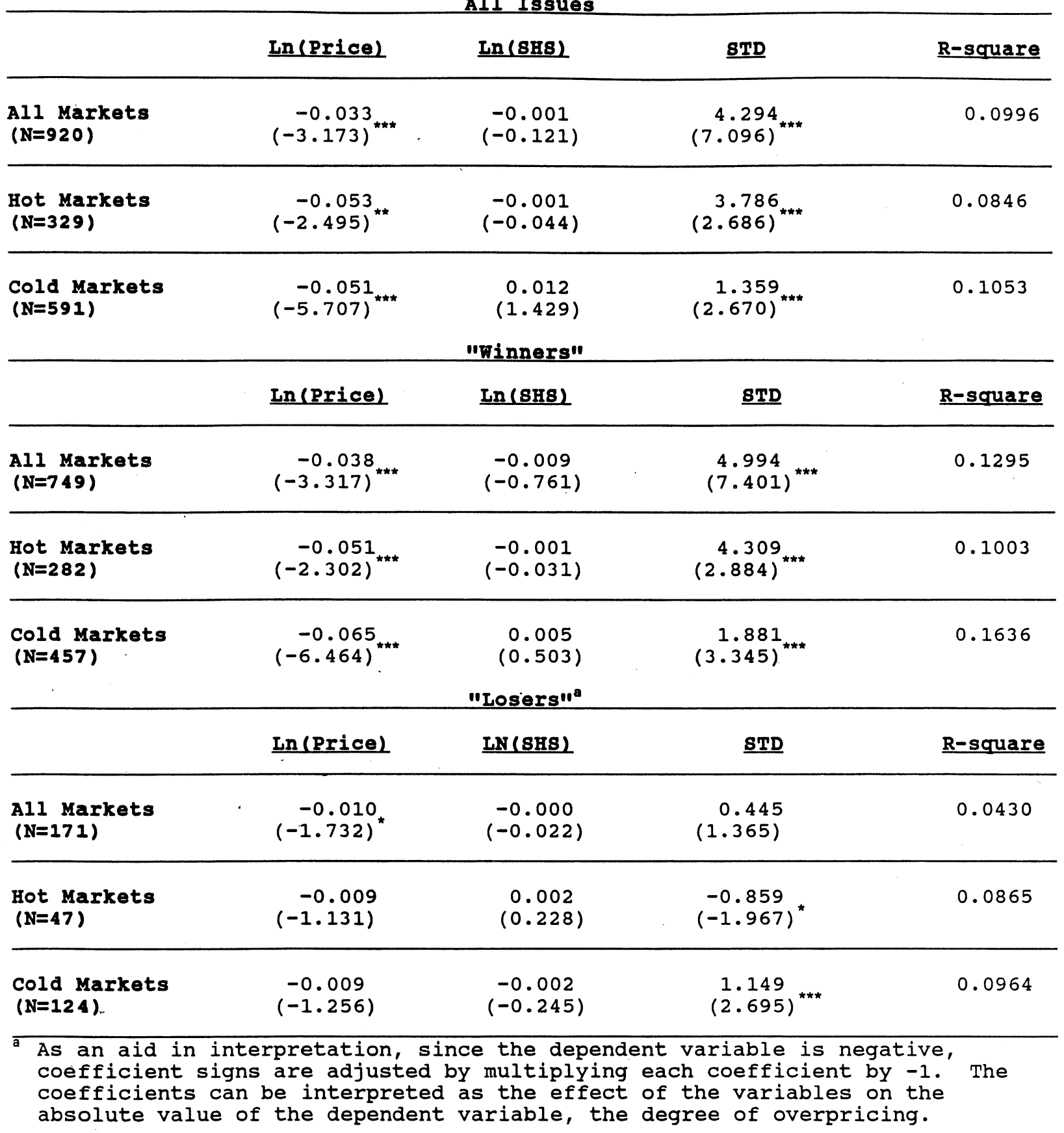




\section{B. Cross-Sectional Regression Results}

The coefficients of the variables of interest are presented in Table 4 with t-statistics provided in parentheses. Panel 1 shows the regression results for all markets as well as for the hot and cold market subsamples. The results for the winners and losers are shown in panels 2 and 3, respectively. PRC and STD are both found to be significant at a 5\% level or higher in both hot and cold markets for all issues and for the subsample of winners (see panels 1 and 2). PRC is negatively related, and STD is positively related to excess returns. In panel 3, overpricing is found to be negatively and significantly related to STD in both hot and cold markets at the $10 \%$ and $1 \%$ level, respectively. The other variables of the model are not significant. The Rsquares of the regressions are low which would be expected, since the actual return on an offering should not be predictable (see Beatty and Ritter, 1986, p. 223). To gain greater insight into the relative impact that each of the variables has on excess returns, the second order partial correlation coefficients of the regression are also examined (see Neter, Wasserman, and Kutner, 1985).

\section{Partial Correlation Results}

An analysis of the percentage of the crosssectional variance in excess returns that is explained by each of the three variables is shown in Table 5. This table contains the second order partial coefficients of determination (partial Rsquare) for each of the three variables. The second order partial coefficient indicates the portion of the variance in excess returns that is explained by the variable of interest after controlling for the effects of the other variables in the model.

As shown in the first panel of Table 5, for the entire sample and the hot market subsample, STD explains the greatest percentage of the variance of excess returns, explaining $5.21 \%$ of the cross-sectional variance in returns for the entire sample, and $2.17 \%$ for the hot market subsample, with price explaining $1.09 \%$ and $1.88 \%$ respectively. In the cold markets, however, PRC has a stronger effect, with a partial coefficient of $5.26 \%$ versus $1.20 \%$ for STD.

The second panel of Table 5 shows the partial coefficients of determination for the underpriced subsample for the respective markets. Again STD has a larger partial coefficient for all markets and hot markets (respectively $6.85 \%$ and $2.91 \%$ ) versus price $(1.46 \%$ and $1.87 \%)$. In cold markets, price dominates, however, explaining $8.27 \%$ of the variation versus $2.36 \%$ for STD. For the overpriced issues, shown in panel 3 , the only significant partial coefficient is STD for both hot and cold markets $(8.25 \%$, significant at the $10 \%$ level and $5.71 \%$, significant at the $10 \%$ level, respectively).

\section{Analysis of the Results}

After adjusting for risk, size appears to provide an incremental explanation for the degree of underpricing observed for new issues. Similar to studies of the size effect observed in the secondary markets, the size effect for new issues is found to be a price effect. Overpricing, in contrast, is negatively related to aftermarket price uncertainty, but is not related to price. These results would be consistent with the existence of an estimation and/or liquidity risk premium for smaller issues.

The existence of a size anomaly in the new issues market does not preclude other theories of underpricing including Rock's $(1982,1986)$ theory based on information asymmetries between informed and uninformed investors or Tinic's implicit insurance hypothesis. The evidence that excess returns are a function of aftermarket price uncertainty and that excess returns in hot issue markets are a function of even greater price uncertainty across issues is consistent with both theories.

An examination of the nature of the size anomaly in the new issues market is left for future studies. Upon general examination, very few of the new issues in the sample were issued at the turn of the year, precluding a January effect. Similarly, there was not evidence of a particular industry effect, such as that observed by Ritter (1984), to provide an alternative explanation for the greater underpricing in hot issue markets.

\section{Summary}

In this paper, the relationship between excess returns and firm size is examined for initial pub- 
The Journal of Applied Business Research - Vol. 6, No. 1

lic offerings of common stock. The study tests the hypothesis that size (offer price and number of shares) is significant in explaining risk-adjusted excess returns for new issues. The hypothesis is supported by the finding that size provides an incremental explanation for the degree of underpricing when risk is held constant. Similar to a previous study by Kross (1985) for secondary issues, the size effect for new issues is found to be a price effect.

Two distinct premiums are observed for IPOs, one for aftermarket uncertainty consistent with recent theories based on information asymmetries or implicit insurance for underwriters; and a second size-related premium for greater estimation risk as observed in previous studies of secondary market security returns. This size-related or estimation risk premium is found to have greater explanatory power in cold issue markets.

TABLE 5: 8ECOND PARTIAL COEFFICIENTS OF DETERMINATION (\%)

"Al1 Issues"

\begin{tabular}{|c|c|c|c|}
\hline & (Price (P) & Shs. Outstanding (SHS) & Uncertainty (STD) \\
\hline & P/SHS, STD & $\underline{\mathrm{SHS} / \mathrm{P}, \mathrm{STD}}$ & STD/P,SHS \\
\hline $\begin{array}{l}\text { All Markets } \\
\mathrm{N}=920\end{array}$ & $\begin{array}{l}1.098^{* * *} \\
(3.173)\end{array}$ & $\begin{array}{l}0.00 \% \\
(0.122)\end{array}$ & $\begin{array}{l}5.21 \%^{* \star \star} \\
(7.096)\end{array}$ \\
\hline $\begin{array}{l}\text { Hot Markets } \\
\mathrm{N}=329\end{array}$ & $\begin{array}{l}1.888^{\star *} \\
(2.495)\end{array}$ & $\begin{array}{l}0.008 \\
\quad 0.043 \\
\end{array}$ & $\begin{array}{r}\left.2.178^{\star \star *}\right) \\
(2.686)\end{array}$ \\
\hline $\begin{array}{l}\text { Cold Markets } \\
\mathrm{N}=591\end{array}$ & $\begin{array}{l}5.268^{\star \star \star} \\
(5.707)\end{array}$ & $\begin{array}{l}0.35 \% \\
(1.429) \\
\end{array}$ & $\begin{array}{r}1.20 \%^{\star \star \star} \\
(2.670)\end{array}$ \\
\hline \multicolumn{4}{|c|}{ "Winners" } \\
\hline & $\underline{\mathrm{P} / \mathrm{SHS} / \mathrm{STD}}$ & $\underline{\mathrm{SHS}} / \mathrm{P}, \mathrm{STD}$ & STD $/ P, S H S$ \\
\hline $\begin{array}{l}\text { Al1 Markets } \\
\underline{N}=749\end{array}$ & $\begin{array}{l}1.468^{\star * *} \\
(3.317)\end{array}$ & $\begin{array}{l}0.08 \% \\
(0.761)\end{array}$ & $\begin{array}{l}6.85 \%^{* * *} \\
(7.401)\end{array}$ \\
\hline $\begin{array}{l}\text { Hot Markets } \\
\underline{\mathrm{N}=282}\end{array}$ & $\begin{array}{l}1.858^{* *} \\
(2.302) \\
\end{array}$ & $\begin{array}{l}0.008 \\
(0.032) \\
\end{array}$ & $\begin{array}{r}2.91 \%^{\star \star \star *} \\
(2.884)\end{array}$ \\
\hline $\begin{array}{l}\text { Cold Markets } \\
\mathrm{N}=467\end{array}$ & $\begin{array}{l}8.27 \xi^{* \star \star} \\
(6.464)\end{array}$ & $\begin{array}{l}0.05 \% \\
(0.502) \\
\end{array}$ & $\begin{array}{r}2.36 \%^{* * *} \\
(3.345) \\
\end{array}$ \\
\hline \multicolumn{4}{|c|}{ "Losers" } \\
\hline & $\underline{P} / \mathrm{SHS}, \mathrm{STD}$ & SHS/P,STD & STD $/ P$, SHS \\
\hline $\begin{array}{l}\text { Al1 Markets } \\
\mathrm{N}=171\end{array}$ & $\begin{array}{l}1.758^{*} \\
(1.732)\end{array}$ & $\begin{array}{l}0.00 \% \\
(0.000)\end{array}$ & $\begin{array}{r}1.10 \% \\
(1.966)\end{array}$ \\
\hline $\begin{array}{l}\text { Hot Markets } \\
\underline{N}=47\end{array}$ & $\begin{array}{l}2.88 \% \\
(1.129) \\
\end{array}$ & $\begin{array}{l}0.13 \% \\
(0.233) \\
\end{array}$ & $\begin{array}{r}8.25 \%^{*} \\
(1.966)\end{array}$ \\
\hline $\begin{array}{l}\text { Cold Markets } \\
\underline{\mathrm{N}=124}\end{array}$ & $\begin{array}{l}1.308^{*} \\
(1.255)\end{array}$ & $\begin{array}{l}0.05 \% \\
(0.246) \\
\end{array}$ & $\begin{array}{l}5.71 \%^{\star \star *} \\
(2.694) \\
\end{array}$ \\
\hline
\end{tabular}


The Journal of Applied Business Research - Vol. 6, No. 1

Hot issue markets are found to be explained by periods of greater aftermarket price volatility whereby higher returns are required as a result of greater risk, consistent with a mean-variance efficient market.

The authors are indebted to Professor Stephen P. Ferris, Virginia Polytechnic Institute and State University for his helpful comments. We would also like to thank the participants in finance workshops at Bowling Green State University and the University of Baltimore for their comments on an earlier draft of this paper. All remaining errors are solely the responsibility of the authors.

\section{NOTES}

1. The CRSP NASDAQ Returns tape calculates returns using the average bid-ask price. Initial day IPO returns are calculated using the initial offer price and the offer day average bid-ask price. Risk-adjusted excess returns were calculated using both the market model and the market model adjusted for infrequent trading (see Brown and Wamer, 1985 and Fowler and Rorke, 1983). Parameters of each model were estimated using ex-post returns. Since the results were similar, only the simple market-adjusted excess returns are reported.

2. Since Brown, Kleidon and Marsh (1983) report that the size effect is linear in the logarithm of size, and size is computed as (Price X Shares outstanding), Kross used the properties of logarithms to formulate his linear model. Kross also included a second equation in his original model to include the earnings/price relationship between $\ln$ (Price) and $\ln$ (EPS). The E/P component, however, was not found to be significant, so it is not included in our model.

3. Ibbotson and Jaffe (1975), for instance, estimated the average bid-ask spread to be approximately 5\% to $10 \%$ of the security price.

\section{References}

1. Amihud, Y. and H. Mendelson. "Asset Pricing and the Bid-Ask Spread." Journal of Financial Economics, 17, pp. 223-249, December 1986.

2. Banz, R. W. "The Relationship Between Return and Market Value of Common Stock." Journal of Financial Economics, 9, pp. 3-18, March 1981.

3. $\quad$ Baron, D. P. "A Model of the Demand for Investment Banking Advising and Distribution Services for New Issues." Journal of Finance, 37, pp. 955-976, Sept. 1982.

4. Barry, C. B. and S. J. Brown. "Differential Information and the Small Firm Effect." Journal of Financial Economics, 13, pp. 213-232, 1984.

5. Beatty, R. P. and J. R. Ritter. "Investment Banking, Reputation, and the Underpricing of Initial Public Offerings." Journal of Financial Economics, 15, pp. 213-232, Jan./Feb. 1986.

6. Belsley, D. E. Kuh, and R. E. Welsch. Regression Diagnostics: Identifying Influential Data and Sources of Collinearity. New York: John Wiley and Sons, 1980.

7. Bloch, E. Inside Investment Banking. Homewood, Illinois: Dow Jones-Irwin, 1986.

8. Blume, M. and R. Stambaugh. "Biases in Computed Returns: An Application to the Size Effect." Journal to Financial Economics, pp. 387-404, November 1983.

9. Booth, J. R. and R. L. Smith. "Capital Raising, Underwriting and the Certification Hypothesis." Journal of Financial Economics, 15, pp. 261-281, Jan./Feb. 1986.

10. Brown, P., A. W. Kleidon, and T. A. Marsh. "New Evidence on the Nature of Size Related Anomalies in Stock Prices." Journal of Financial Economics, 12, pp. 105-127, June 1983.

11. Brown, S. L. and J. B. Warner. "Using Daily Stock Returns: The Case of Event Studies." Journal of Financial Economics, 8, pp. 205-258, June 1985 .

12. Carter, R. and S. Manaster. "Initial Public Offerings and Underwriter Reputation," University of Utah, Working Paper, 1987.

13. Chalk, A. J. and J. W. Peavy, III. "Understanding the Pricing of Initial Public Offerings," Southern Methodist University, Working Paper, November 1985.

14. Chalk, A. J. and J. W. Peavy, III. "IPOs: Why Individuals Don't Get 'Hot' Issues." AAII Journal, 9, pp. 16-20, March 1987.

15. Chalk, A. J. and J. W. Peavy, III. "Initial Public Offerings: Daily Returns, Offering Types, and the Price Effect." Working Paper presented at the Financial Management Association Meeting, New York, N.Y., October 1986.

16. Christie, A. A. "The Stochastic Behavior of Common Stock Variances: Value, Leverage and Interest Rate Effects." Journal of Financial Economics, 10, pp. 407-432, December 1982.

17. Dimson, E. "Risk Measurement When Shares Are Subject to Infrequent Trading: Comment," Journal of Financial Economics, pp. 197-216, June 1979.

18. Fowler, D. and C. H. Rorke. "Risk Measurement When Shares are Subject to Infrequent Trading: Comment," Journal of Financial Economics, 12, pp. 279-283, August 1983.

19. Ibbotson, R. G. "Price Performance of Common Stock New Issues," Journal of Financial Economics, pp. 235-272, September 1975.

20. Ibbotson, R. G. and J. Jaffe. "Hot Issue Markets," Journal of Finance, 30, pp. 1027-1042, September 1975.

21. Johnson, J. M. and R. E. Miller. "Investment Banker Prestige and the Underpricing of Initial Public Offerings." Financial Management, pp. 19-29, Summer 1988.

22. Klein, B. and K. Leffler. "The Role of Market Forces in Assuring Contractual Performance." Journal of Political Economy, 89, pp. 615-641, August 1981.

23. Klein, R. W. and V. S. Bawa. "The Effect of Limited Information and Estimation Risk on Optimal Portfolio Diversification." Journal of Financial Economics, 5, pp. 89-111, 1977.

24. $\quad$ Kross, W. "The Size Effect Is Primarily a Price Effect." The Journal of Financial Research, 8, pp. 169-179, Fall 1985.

25. Miller, R. E. and F. K. Reilly. "An Examination of Mispricing, Returns, and Uncertainty for Initial Public Offerings." Financial Management, pp. 33-38, Summer 1987.

26. Neter, J., W. Wasserman, and M. H. Kutner. Applied Statistical Models, 2nd. ed. Homewood, Illinois: Richard D. Irwin, Inc., pp. 
507-508, 1985.

27. Reinganum, M. "Misspecification of Capital Asset Pricing: Empirical Anomalies Based on Earnings Yields and Market Values." Journal of Financial Economics, pp. 19-46, March 1981.

28. Ritter, J. R. "The 'Hot Issue Market of 1980'." Journal of Business, 57, pp. 215-240, April 1984.

29. Ritter, J. R "A Theory of Investment Nanker Contract Choice." Working Paper, University of Michigan, Ann Arbor, 1987.

30. $\quad$ Ritter, J. R. "The Costs of Going Public." Journal of Financial Economics, forthcoming.

31. $\quad$ Rock, K. R. "Why New Issues Are Underpriced." Journal of Financial Economics, 15, pp. 187-212, Jan./Feb. 1986.

32. Rock, K. R. "Why New Issues Are Underpriced," Unpublished Ph.D. dissertation (University of Chicago, Chicago, Illinois), 1982.

33. Roll, R. "On Computing Mean Returns and the Small Firm Premium." Journal of Financial Economics, 12, pp. 371-386, June 1983.

34. Roll, R. "VAS IST DAS? The Turn-of-the-Year Effect and the Return Premia of Small Firms." Journal of Portfolio Management, pp. 18-28, Winter 1983.

35. Smith, C. W. "Investment Banking and the Capital Acquisition Process." Journal of Financial Economics, pp. 3-29, Jan./Feb. 1986.

36. Tinic, Seha M. "Anatomy of Initial Public Offerings of Common Stock." Journal of Finance, pp. 789-822, September 1988. 